\title{
RELATIONSHIP QUALITY AND CUSTOMER RETENTION AMONG FAST FOOD VENDORS IN EKITI STATE, NIGERIA
}

\author{
Aliu Akindele Anifowose ${ }^{1}$, Ajiboye Folasade Alaba² \\ and Ogunode Philips Olatunde ${ }^{3}$ \\ ${ }^{1}$ Department of Purchasing and Supply, The Federal Polytechnic, PMB 5351, Ado- \\ Ekiti, Ekiti State, Nigeria \\ ${ }^{2}$ Department of Marketing, Osun State Polytechnic, P.M.B 301, Iree Osun State, \\ Nigeria. Email: ajiboyefolasade@gmail.com \\ ${ }^{3}$ Department of Marketing, The Federal Polytechnic, PMB 5351, Ado-Ekiti, Ekiti \\ State, Nigeria. Email: philips29g@yahoo.com.
}

Cite this article:

Aliu A.A., Ajiboye F.A., Ogunode P.O. (2021),

Relationship Quality and Customer Retention Among Fast Food Vendors in Ekiti State, Nigeria. British Journal of Management and

Marketing Studies 4(2), 89103. DOI: $10.52589 / \mathrm{BJMMS}-$ XALVKOOU.

\section{Manuscript History}

Received: 10 April 2021

Accepted: 11 May 2021

Published: 29 June 2021

Copyright $\odot 2020$ The Author(s). This is an Open Access article distributed under the terms of Creative Commons AttributionNonCommercial-NoDerivatives 4.0 International (CC BY-NC-ND 4.0 ), which permits anyone to share, use, reproduce and redistribute in any medium, provided the original author and source are credited.
ABSTRACT: The study examined the effect of relationship quality on customer retention in the fast-food industry. Specifically, the study determined the effect of personnel quality as well data base marketing on the quality of the relationship between eateries and their clients. In this survey, a questionnaire was the instrument for data collection. The population of the study consists of a staff of major eateries in the Ado-Ekiti metropolis while a stratified random sampling technique was used to select 52 staff who took part in the study. Data collected were analysed using chi-square. The research finding revealed that personnel quality and database marketing both have a significant effect on relationship quality in eateries. It was therefore recommended that fast food firms should continually train their personnel to be more empathetic and effective especially in the areas of personnel-customer relationship, appearance, quick delivery of services and customer complaint handling style.

KEYWORDS: Relationship, Relationship Quality, Customer, Customer Retention 


\section{INTRODUCTION}

In today's competitive business environment, losing a customer is very costly as it can cost up to 5 times more to acquire a new customer than keep an existing customer. Moreover, old customers bring more profit than new ones (Ward, 2009). As a result, the establishment and development of mutually beneficial relationships with customers are of paramount importance for Eateries. Service industries, especially Eateries, are facing stiff competition in a market where retaining customers is part of their core strategy to gain a competitive advantage.

'Relationship quality' is one of the means used to measure performance in service industries, especially in eateries. The term can be defined as the quality of interaction between the organization and its customers (Giovanis 2015). Previous research has shown that relationship quality can even replace service quality and customer satisfaction (Giovanis 2015). There are circumstances in which customers are willing to place relationship quality over service quality. Gummesson (1987) states that relationship quality influences the quality recognized by the client, whereas Storbacka, Strandvik, and Grönross (1994) postulate that service quality and client satisfaction have a positive impact on relationship quality.

On the other hand, 'customer retention' is finding ways to make the customers who you acquire become repeat buyers who are loyal to your brand. It is advantageous for businesses to retain customers, since retaining customers cost businesses less than acquiring new customers. According to Shcheglova and Shcheglov (2010), there are various studies that state that focuses on customer retention is less expensive than acquisition and can be more profitable.

Relationship quality had been viewed, as a vital factor in determining customer retention in an organization. Although the association between relationship quality and customer retention had been understood intuitively, few researchers have attempted to measure the impact of relationship quality on customer retention. The current study addresses this issue in the context of eateries.

\section{Statement of the Problem}

Maintaining a quality relationship with customers is one of several ways to gain a competitive advantage. Eateries can even attempt to strategize relationship quality as their core competency. Eateries, by nature of what they do and the industry in which they operate, are expected to create and maintain a long and lasting relationship with their clients. With this, they will be able to keep their customers for a long and profitable duration. Unfortunately, it appears Customer retention is not given the attention it desires by service firms especially the fast-food industry and this has adversely affected the level of profit accrued to them. According to Crosby et al (1990), 'Marketing is to establish, maintain and enhance relationships with customers and other parties at a profit so that the objectives of the parties involved are met. Thus, maintaining a healthy relationship with customers enables Eateries to retain their customers and helps them to remain competitive in the industry. Maintaining quality relationships will not only be profitable to eateries but will at long run boost the overall economy of Nigeria.

More so, the failure of eateries to keep the database of customers seems to be responsible for the inability to contact them when necessary and to unravel the reason for their disconnection with the business. Customers want to be recognized as stakeholders whose relevance to the survival of firms cannot be undermined. 
It is due to the sequel to the aforementioned problems that this study seeks to examine the effect of relationship quality on customer retention in Ado-Ekiti, Ekiti, Nigeria.

\section{Objectives of the Study}

The main objective of this study is to examine the effect of relationship quality on customer retention. The specific objectives include:

1. To find out the effect of personnel quality on customer retention

2. To examine the relationship between database marketing and customer retention.

\section{Research Hypotheses}

The following hypotheses stated in their null forms will be tested in this study

1. Personnel quality has no significant effect on customer retention

2. There is no significant relationship between Database marketing and customer retention.

\section{LITERATURE REVIEW}

\section{Relationship Quality}

The importance of relationship quality as a construct in contemporary marketing studies is reflected in numerous studies over the last twenty years. It includes the definitions of RQ employed, its dimensions, and determinants. As already noted, there is no consensus on a definition of RQ (e.g. Palmatier, R.W, Dant, Grewal, and Evans 2006; Sheth and Parvatiyar 2002). However, there is some degree of consensus that RQ is a higher-order construct comprising several different, though related dimensions (Crosby Evans, and Cowles 1990; Dorsch 1998; Dwyer and Oh 1987; Hennig-Thurau 2001; Kumar, Sheer, Steenkamp 1995; Roberts, Varki, Brodie. 2003; Woo and Ennew 2004). Other studies provide a more contextspecific definition of RQ. For example, Moorman (1992) defines RQ as 'the degree to which users view user-researcher interactions as productive'. In a different context, Huntley (2006) views RQ as the degree to which buyers are satisfied over time with the overall partnership as manifested in product quality, service quality, and value for money. In a context that can be seen as reflecting a people-based, inter-organizational approach to RQ, Holmlund (2001) provides a working definition that views RQ as 'the joint cognitive evaluation of business interactions by key individuals in the dyad, comparatively with potential alternative interactions'.

It should be noted that even context-specific definitions implicitly agree that RQ is about an interaction assessment. Some relate to a specific outcome of such an interaction (e.g. Moorman et al. 1992), while others refer to an evaluation of the interaction over time (e.g. Holmlund 2001, and Boles et al. 1997) and imply that it needs to be a joint evaluation, which is more in line with the 'two-way' nature of relationships. However, the various approaches to modeling RQ draw primarily on buyer-only perspectives, a gap which is probably due to the difficulties inherent to collecting and analyzing data from both sides of the dyad. It has been argued that this absence of consensus in terms of definition may also be due to the various levels at which 
relationships seem to develop, e.g. structural, economical, and social (e.g. Holmlund and Tornroos 1997; Walter 2003) as well as the context-specific nature of RM (Palmatier et al. 2006; Walter 2003). However, we agree with Woo and Ennew (2004) who argue that 'to progress the conceptualization of RQ, we should accept a very general perspective on the meaning of the term, and focus instead on identifying the constructs that create relationship quality'.

To propose a meaningful definition of RQ, we first consider the concept of RQ, as the relevance of RQ could vary. Several authors suggested that RM is most relevant in B2B contexts, and should be confined to situations that involve a high degree of interpersonal interaction (O'Malley and Tynan, 1999), since RM in consumer markets may be 'more rhetoric than reality' (O'Malley and Tynan, 2000). This is confirmed in Palmatier et al.'s (2006) metaanalysis which showed that RM is more effective in those situations in which buyers perceive relationships as being more important, i.e. service settings as compared to product offerings, channel exchanges as compared to direct exchanges and business markets as compared to consumer markets.

However, the marketing literature (e.g. Gümmesson 1995; Vargo and Lusch 2004) argues more and more against the traditional distinction between goods and services. Indeed, increasingly many goods have a service element and many services have tangible components. This renders traditional arguments about RM and RQ being relevant for services rather than goods questionable to a greater extent. The question is under what circumstances relationships matter - because where relationships matter, so will RM and RQ.

These circumstances include aspects such as information asymmetries (which are also associated with vulnerability to opportunistic behavior and, thus, highlights the importance of trust), high degrees of asset specificity (e.g. contracts; systems links), high levels of uncertainty, frequency of interactions, relatively significant levels of expenditure, need for some degree of customization/personalization, and potential/need for co-creation (Berry 1983; Crosby et al. 1990). In essence, all of these conditions are proxies for a customer's need for a relationship.

Pure service environments seem to be particularly suitable for assessing RQ, due to the absence of a physical item of the transaction (Berry 2002; Haytko 2004) and the importance of personto-person interaction. In such contexts, "relationship quality from the customer's perspective is achieved through the salesperson's ability to reduce perceived uncertainty" (Crosby et al, 1990). Indeed, frequently, relationship managers are the primary contact point for the buyer and have a significant influence on the level of quality, especially in those situations where the customer perceives that 'the salesperson is the company' (Crosby et al. 1990). It has further been argued that the success or failure of relationships depends strongly on the way relationship managers' act, as well as on the strength of the social bonds between them and their counterparts in firms (Bejou, Ennew, and Palmer 1998; Boles 1997; Bolton et al. 2003; Gümmesson 1994; Pressey and Mathews 2000). Based on the literature relating to relational governance and the foregoing discussion, we recognize that RM and RQ are most appropriate when exchange relationships are characterized by frequency, uncertainty, and asset specificity, where there is a significant dependence on trust and where interpersonal interactions are important. In practice, this may dominantly refer to B2B transactions and service transactions, but as we argued above, RM and RQ are not automatically restricted to these domains. Against this background, we suggest an adaptation of Holmlund's (2001) definition as the one that best 
reflects the nature and domain of RQ: '[RQ is] the cognitive evaluation of business interactions by key individuals in the dyad, comparatively with potential alternative interactions'. Unlike Holmlund (2001) we do not argue that relationship quality requires a joint evaluation by key individuals in the dyad, instead, we propose that each party will have their own perception of RQ. Our definition is compatible with Crosby et al's (1990) view of RQ as a higher-order construct, which is now widely accepted. Having established a definition of RQ and its domain, the following will provide a review of the dimensions and determinants used to model RQ.

\section{Dimensions of Relationship Quality}

A large number of constructs have been employed as determinants and dimensions of RQ and there is little consensus as to how the constructs should be modeled. It should also be mentioned that the measurement of RQ has predominantly been approached from the customer's perspective. In terms of the dimensions of RQ, there is a tendency to emulate Crosby et al.'s (1990) conceptualization as a higher-order construct including satisfaction with the salesperson's performance and trust in the salesperson (Bejou 1996; Boles 2000; Lagace 1991; Leuthesser 1997; Parsons 2002; Vieira 2001; Wray 1994). This approach forms the basis for many studies modeling RQ, by either using the same two dimensions (e.g. Bejou 1996; Boles 2000; Lagace 1991) or including additional dimensions (e.g. Naudé and Buttle 2000; Walter 2003). There is almost an equal split between empirical work that employs satisfaction and trust as first-order dimensions of RQ and those that also include commitment. More recent work almost exclusively regards RQ as a higher-order construct comprised of trust, satisfaction, and commitment (e.g. Roberts 2003; Walter 2003; Ivens 2004; Ulaga and Eggert 2006; Ivens and Pardo 2007). Trust, satisfaction, and commitment have also been referred to as the building blocks of RM (e.g. Crosby et al. 1990; Kempeners, 1995). Commitment appears to be the most controversial construct, as it has also frequently been modeled as a determinant of RQ. It is interesting to note that, since the publication of Morgan and Hunt's (1994) 'Commitment-Trust Theory of Relationship Marketing', researchers started to add commitment as an RQ dimension, alongside trust and satisfaction (e.g. Dorsch 1998, Smith 1998, DeWulf 2001; Hennig-Thurau 2002; Roberts 2003; Walter 2003; Ivens 2004; Ulaga and Eggert 2006; Ivens and Pardo 2007; Rauyruen and Miller 2007). This is somewhat in conflict with the key mediating variable model (KMV) of Morgan and Hunt (1994) which posits commitment as a consequence of trust.

\section{Determinants of Relation Quality}

Empirical studies have included a plethora of constructs as determinants of RQ. Comparison of the various constructs and their respective measures suggests some overlaps. For example, ethics (Bejou et al. 1998; Bejou 1996 and Wray 1994) and ethical profile (Dorsch 1998) refer to the same concept. Equally, relational behavior (Leuthesser, 1997) is equivalent to Crosby et al's (1990) relational selling behavior. Attempts have been made to identify possible overlaps. For example, Parsons (2002) combined the construct "similarity" with "shared values".

The most commonly employed determinants of RQ are: seller's service domain expertise (e.g. Crosby et al. 1990; Lagace 1991, Wray 1994; Bejou 1996; Parsons 2002), relational selling behavior (e.g. Crosby 1990; Lagace 1991; Parsons 2002; Boles 2000; Leuthesser 1997), similarity or mutual goals (e.g. Crosby et al. 1990; Lagace 1991; Parsons 2002; Smith 1998; Boles 2000; Huntley 2006; Vieira 2001); relational value/value, relational benefits (e.g. Storbacka 1994; Ulaga and Eggert 2006; Hennig- Thurau 2002; Parsons 2002), communication 
(Smith, 1998), customer orientation (Wray 1994), and relational investment (DeWulf et al. 2001). Although trust and satisfaction are seen by the majority of studies as dimensions of RQ (see earlier), several studies included trust (Moorman 1992; Wong and Sohal 2002; Huntley 2006) or satisfaction (Storbacka 1994; Hennig-Thurau and Klee 1997) as precursors (i.e. determinants of RQ. However, this approach was primarily used when RQ was represented by a unidimensional measure. Commitment has also been modeled as a key determinant of RQ (e.g. Parsons 2002; Storbacka et al. 1994; Vieira 2001). However, studies that treated commitment as a precursor to RQ, also modeled trust as an antecedent of RQ (Huntley 2006; Wong and Sohal 2002), or employed commitment to predict a unidimensional measure of RQ (Storbacka 1994, Wong and Sohal, 2002), exceptions being the studies by Parsons (2002) and Vieira (2001). The lack of consensus on the determinants of RQ is partly explained by the context-dependency of the studies. Equally, it appears to depend on whether RQ is seen as a highly generic uni-dimensional construct or a higher-order construct based on distinct dimensions. Indeed, RQ and its determinants and dimensions have been developed, operationalized, and tested empirically under a combination of various research settings, ranging from goods vs. services industries to business-to-business (B2B) vs. business-toconsumer (B2C) relationships, as well as from a range of perspectives, e.g. the seller's perspective, the buyer's perspective, and the dyadic perspective. For example, in the context of investment and financial services, Wray (1994) used the same dimensions of RQ as in Crosby et al. (1990) and included constructs such as ethics and expertise as determinants of RQ, probably due to the perceived complexity of investment and financial services.

\section{Elements of Relationship Quality}

\section{Satisfaction}

The Expectation-Confirmation Theory (ECT) was proposed by Oliver (1980) to study consumer satisfaction and re-purchase behavior. The ECT theory states that consumers firstly form an initial expectation prior to purchase, and then build perceptions about the performance of the consumed product/service after a period of initial consumption. Next, consumers will decide on their level of satisfaction based on the extent to which their expectation is confirmed by comparing the actual performance of the product/service against their initial expectation of the performance. Consequently, satisfied consumers will form repurchasing intentions.

Satisfaction can be described as an "evaluation of the perceived discrepancy between prior expectation and the actual performance of the product" (Oliver, 1999). Satisfaction is closely related to service quality and consists of both a behavioral dimension created by experience, as well as a mental dimension, created by worked-up attitudes (Oliver, 1999). Relationship satisfaction is an affective or emotional state toward a relationship, typically evaluated cumulatively over the history of the exchange (Palmatier et al. 2006). The satisfaction component of relationship quality is about customers' evaluation of the relationship with the fast-food firm's product. The major source of relationship satisfaction is a history of positive interaction with the host/hostess in service. The customer's best assurance of future relationship quality is a continuous history of personalized, good interaction with fast-food firm's host/hostess (Crosby et al. 1990). 


\section{Trust}

According to the theory of reasoned action (TRA), an individual's belief towards a behavior is an immediate determinant of his intention to perform a behavior (Fishbein and Ajzen, 1975). (Mayer et al., 1995) have extended the TRA to support the modeling of customer trust in the fast-food firm. Trust is a crucial ingredient of any successful fast-food industry, and privacy is the key element in building citizen's trust in eatery service (Kim et al., 2009). Customer trust can be defined as a set of beliefs held by an eateries consumer concerning certain characteristics of the host/hostess of the fast-food firm, as well as the possible behavior of the management in the future (Coulter and Coulter, 2002). Lee and Lin (2005) suggested that trust encourages customers purchasing and affects customer attitudes towards repeat purchases.

Trust is an important indicator of relationship quality. Only when a person trusts the trustee will he/she be likely to perceive that there is a high-quality relationship between the trustee and $\mathrm{him} / \mathrm{her}$. A relationship that lacks trust is unlikely to be perceived as high quality. It is also important to note that trust is difficult to foster, can be shaken easily, and is extremely difficult to rebuild (Shneiderman 2000).

\section{Commitment}

Commitment is defined as the enduring desire to maintain a valued relationship (Palmatier et al. 2006), customer commitment is one of the most commonly studied key elements in relationship quality studies (Hsieh \& Li 2008). Commitment has often been conceptualized as a multi-dimensional construct. For instance, Gundlach (1995) proposed three components of commitment: an instrument component of some form of investment, an attitudinal component described as an affective commitment or psychological attachment, and a temporal dimension indicating that the relationship exists over time. Thus, a committed customer has invested time and emotion into the relationship with a service provider, shows affection toward it, and is willing to maintain this relationship for a certain period, sometimes even at the cost of shortterm benefits.

Commitment is an essential ingredient for successful long-term relationships because committed customers are the basis for business continuity and bring future value or benefits to those they are committed to (Lemon 2001). Committed customers feel loyal to the service provider and are willing to put in extra efforts or even sacrifice short-term benefits to maintain the relationship. They are also more tolerant of minor errors from the service provider. Maintaining this commitment to a specific marketplace is especially important in e-commerce, given the low cost of switching to different online marketplaces. For this study, the commitment dimension is defined as the customers' future intention to return indicating that the relationship exists over time to predict the continuity of the relationship with the fast-food firm that provides quality services.

\section{Customer Retention}

Customer retention can be defined as how companies or organizations can maintain the existing customers' base on establishing good relations with all who buy the company's product, (Kotler, 2008). Customer retention marketing is a tactically driven approach based on customer behavior. Johnson (1998) outlined some philosophies of retention-oriented which include: 
1. Retention marketing requires allocating market resources: the company has to realize some marketing activities for customers to generate higher profits in the company. The company can keep its budget flat or shrink it while increasing sales and profits.

2. Active customers are retained: customers are likely to feel they are in control and smart about choices they make and they like to feel good about their behavior. Marketers take advantage of this by offering promotions of various kinds to get consumers to engage in a behavior and feel good about doing it.

3. Retaining customers means keeping them active with the company. If the company does not keep them active they will slip away and eventually no longer be customers.

4. Marketing is a conversation between customers and the marketer. Marketing with customer data is a highly evolved and valuable conversation but it has to be back and forth between the customer and the marketer because the marketer must listen to what the customer is saying to better their products or services offered.

\section{Customer Retention Strategies}

\section{Attracting Customers}

Customers are smarter, more price-conscious, more demanding when products are not conducive to them, and offered better products from competitors. According to Cooper and Kaplan, (May-June 1991), it is not to produce satisfied customers because several competitors can do this, but to produce delighted and loyal customers. This means customers are not only to be satisfied with products and services but must be retained in the company. Companies seeking to expand their profits and sales have to spend time and resources searching for new customers.

To start, the company develops adverts and places them in media that will reach new prospects, it also sends direct mail and makes phone calls to attract new prospects.

According to Gitomer (1998), to attract new prospects, the company can use;

a) Product Development: It involves the development of new products for the existing market to;

i. Meet changing needs of customers.

ii. Match new competitive offerings.

iii. Take advantage of new technology.

iv. Meet the needs of specific market segments.

Product development is appropriate when changing needs and tasks results in the emergence of new segments or when competitive and technological changes motivate firms to modify their product lines.

b) Packaging: This is the development of a container and graph design for a product. It is all the activities involved in designing and producing the container or wrapper for a product. 
c) Promotions: It is the use of any short-term incentives to encourage customers to interact with the company.

d) Advertising: This is a paid form of non-personal communication about a company, its product, or its activities and used to inform, persuade and remind.

\section{The Need for Customer Retention}

According to Senge (2001), most marketing theory and practice centers are on the art of attracting new customers rather than on retaining and cultivating existing ones, the emphasis traditionally has been on making sales rather than building relationships. A company would be wise to measure customer satisfaction regularly because the key to customer retention is customer satisfaction. A highly satisfied customer stays loyal longer, buys more as the company introduces new products and upgrades existing products, talks favorably about the company and its product, pays less attention to competing brands and is less sensitive to price, offers product or service ideas to the company and cost less to serve than new customers because transactions are routine. Some companies think that getting a sense of customer satisfaction is by tallying customer complaints, but $96 \%$ of unsatisfied customers do not complain but many just stop buying.

\section{METHODOLOGY}

The study adopted a survey design in which structured questionnaires were used to acquire the data for the study. The study area was Ado-Ekiti, the capital of Ekiti State. Ado-Ekiti was chosen because it is the only local government area that was analyzed, ranches of all the eateries operating in Ekiti state. More so, it allows the researchers to randomly select from an array of eateries that operate in Ekiti state.

The population of the study consists of a staff of eateries in Ekiti state. A stratified sampling technique was used to select 52 staff of the selected eateries in Ado-Ekiti. The selected Eateries include Portofino, Take away, Danke Food, Tantalizer, and Friendlies fast foods. Of these, 18 staff was selected from Portofino, 7 from Take-away fast food, 9 from Danke food, 13 from Tantalizer, and 5 from Friendly's Fast-food. The source of data for this research was a primary source. The primary data was gathered through self-designed questionnaires that were administered to some selected staff of major eateries in Ado-Ekiti.

Data collected were analyzed using Microsoft Excel. The research hypotheses were tested using chi-square. Chi-square was statistically defined as:

Where:

$$
\begin{gathered}
\mathrm{X}^{2}=(\mathrm{Fo}-\mathrm{Fe})^{2} \\
\mathrm{Fe}
\end{gathered}
$$

Fo: Observed frequency

Fe: Expected frequency

$\square^{2}=$ Greek symbol used to denote the test statistic 
The degree of freedom is given by

$(\mathrm{R}-1)(\mathrm{C}-1)$

Where

$\mathrm{R}=$ number of rows

$\mathrm{C}=$ number of columns

The level of significance used in this test was $5 \%$ or 0.05 .

Decision rule - Reject $\mathrm{H}_{0}$ if $\mathrm{P}$-value $\leq 0.05$

\section{Test of Hypotheses}

Hypothesis One: There is no significant relationship between personnel quality and customer retention.

P value $=0.000$

Decision rule: Reject $\mathrm{H}_{0}$ if $\mathrm{P}$ value $\leq 0.05$

Decision: Since the P-value of 0.000 is less than 0.05 , which is the chosen level of significance. We reject the null hypothesis and accept the alternative hypothesis. Therefore, we conclude that there is a significant relationship between personnel quality and customer retention.

Hypothesis Two: There is no significant relationship between database marketing and customer retention.

P value $=0.000$

Decision rule: Reject $\mathrm{H}_{0}$ if $\mathrm{P}$ value $\leq 0.05$

Decision: Since the P-value of 0.000 is less than 0.05 , which is the chosen level of significance, we reject the null hypothesis and accept the alternative hypothesis. Therefore, we conclude that there is a significant relationship between database marketing and customer retention.

\section{DISCUSSION OF FINDINGS}

Based on the above analysis, the study found that personnel quality influences customer retention in the fast-food industries. Personnel quality in this regard could be classified as personal characteristics of an individual employee's personality like honesty, assertiveness, flexibility, problem-solving, friendliness, intelligence, leadership, enthusiasm, and a good sense of humor. This finding agrees with the view of Crosby (1990). According to Crosby (1990), relationship quality from the customer's perspective is achieved through the salesperson's ability to reduce perceived uncertainty. 
More so, this study strongly indicates that there is a relationship between database marketing and customer retention. Database marketing involves collecting customer data like names, addresses, emails, phone numbers, transaction histories, customer support tickets, etc. This view is supported by Johnson (1998) which ascertained marketing with customer data is a highly evolved and valuable conversation but it has to be backed and forth between the customer and the marketer because the marketer must listen to what the customer is saying to better their products or services offered.

\section{CONCLUSION}

This study was carried out to examine the effect of relationship quality on customer retention. Based on the findings of the study, it could be concluded that personnel quality (including personnel interaction, appearance, quick delivery of services, and complaint handling style) and keeping valuable data of customers could go a long way in strengthening the chord of the relationship between fast food firms and their customers. Leveraging these key attributes would enhance the competitiveness of Eatery firm and also improve customer retention.

\section{RECOMMENDATIONS}

Based on the findings of this study, the following recommendations are advanced:

1. It is highly recommended that fast food firms should continually train their personnel to be more effective especially in the areas of personnel-customer relationship, appearance, quick delivery of services, and customer complaint handling style.

2. Fast-food firm managers should keep records of their clients and update them biannually. They should also find out from time to time if there are menu options that can be added, removed, or offered to lure in new business. They should publicize their new menu offerings to encourage loyal customers to return and new customers to venture in to try out the Fast-food firm.

\section{REFERENCES}

Bejou, D., B. Wray, and T. Ingram (1996), "Determinants of Relationship Quality: An Artificial Neural Network Analysis," Journal of Business Research, 36, 137-43.

Bejou, D., C. Ennew, and A. Palmer (1998), "Trust, Ethics and Relationship Satisfaction," International Journal of Bank Marketing, 16 (4), 170-75.

Berry L. A and Zeithaml Parsuraman (2005). Customer Satisfaction, New Jersey

Berry, L. (1983), "Relationship Marketing," in Emerging Perspectives on Services Marketing, L. Berry and G. Shostack and G. Upah, Eds. Chicago: American Marketing Association.

Berry, L. (2002), "Relationship Marketing of Services - Perspectives from 1983 and 2000," Journal of Relationship Marketing, 1 (1), 59-77.

Boles, J. S., H. C. Barksdale, and J. Johnson (1997), "Business Relationships: An Examination of The Effects of Buyer-Salesperson Relationships on Customer Retention 
and Willingness to refer and Recommend," Journal of Business \& Industrial Marketing, 12 (3/4), 253-65.

Bolton, R., A. Smith, and J. Wagner (2003), "Striking the Right Balance: Designing Service to Enhance Business-to-Business Relationships," Journal of Service Research, 5 (4), 271-91.

Coulter, K. and R. Coulter., "Determinants of Trust in a Service Provider: The Moderating Role of Length of Relationship", Journal of Services Marketing, Vol. 16, No. 1, 2002, pp. 35-50.

Crosby, L., K. Evans, and D. Cowles (1990), "Relationship Quality in Services Selling: An Interpersonal Influence Perspective," Journal of Marketing, 54 (July), 68-81.

Crosby, Lawrence A., Kenneth R. Evans, and Deborah Cowles (1990), "Relationship Quality in Services Selling: An Interpersonal Influence Perspective," Journal of Marketing, 54 (July), 68-81.

Dorsch, M., S. Swanson, and S. Kelley (1998), "The Role of Relationship Quality in the Stratification of Vendors as Perceived by Customers," Journal of the Academy of Marketing Science, 26 (2), 128-42.

Dwyer, P., H. Schurr, and S. Oh (1987), "Developing Buyer-Seller Relationships," Journal of Marketing, 51 (April), 11-27.

Fishbein, M. and I. Ajzen.). Belief, Attitude, Intention, and Behavior: An Introduction to Theory and Research. Addison- Wesley, 1975.

Gartner (2009), Customer Relationship Management, IT News Africa.

Giovanis, A.; Athanasopoulou, P.; and Tsoukatos, E. (2015). The role of service fairness in the service quality-relationship quality-customer loyalty chain: An empirical study, Journal of Service Theory and Practice 25(6), 744-776. DOI: https://doi.org/10.1108/JSTP1120130263 https://doi.org/10.1108/03090560610648075

GUMMESSON, E. (1987) "The New Marketing: Developing Long-Term Interactive Relationships", Long Range Planning, 20, 4, pp. 10-20.

Gümmesson, E. (1994), "Is Relationship Marketing Operational?" Proceedings of the $23^{\text {rd }}$ EMAC Conference, Maastricht.

Gümmesson, E. (1995), "Relationship Marketing: Its Role in the Service Economy," in Understanding Services Management, W. Glyn and J. Barnes, Eds. New York: John Wiley \& Sons.

Gundlach, G.T., Achroi, R.S., and Mentzer, J.T., "The Structure of Commitment in Exchange", Journal of Marketing Vol. 59, 1995, pp. 78-92.

Haytko, D. (2004), "Firm-to-Firm and Interpersonal Relationships: Perspectives from Advertising Agency Account Managers," Journal of the Academy of Marketing Science, 32 (3), 312-28.

Hennig-Thurau, T., K. Gwinner, and D. Gremler (2002), "Understanding Relationship Marketing Outcomes: An Integration of Relational Benefits and Relationship Quality," Journal of Service Research, 4 (3), 230-47.

Holmlund, M. (2001), "The D\&D Model: Dimensions and Domains of Relationship Quality

Holmlund, M. and T. Strandvik (1997), "Perception Configurations in Business Relationships," Management Decision, 37 (9), 686-96.

Huntley, J. (2006), "Conceptualization and Measurement of Relationship Quality: Linking Relationship Quality to Actual Sales and Recommendation Intention," Industrial Marketing Management, 35, 703-14.

Ivens, B.S. (2004), "Industrial Seller' Relational Behavior: Relational Styles and their Impact on Relationship Quality," Journal of Relationship Marketing, 3 (4), 27-43. 
Ivens, B.S. and C. Pardo (2007), "Are Key Account Relationships Different? Empirical Results on Supplier Strategies and Customer Reactions, "Industrial Marketing Management, 36, 470-82.

Keating, B., R. Rugimbana, and A. Quazi (2003), "Differentiating between Service Quality and Relationship Quality in Cyberspace," Managing Service Quality, 13 (3), 217-32.

Kempeners, M. (1995), "Relationship Quality in Business-to-Business Relationships," Proceedings of the 11th IMP Conference, 3rd Vol., 1629-39.

Kim, D. J., L. F. Donald, and H. Raghav Rao, (2009). Trust and Satisfaction, Two Stepping Stones for Successful Ecommerce Relationships: A Longitudinal Exploration. Information Systems Research, 20(2), 237-257.

Kumar, N., L. Scheer, and J. Steenkamp (1995), "The Effects of Perceived Interdependence on Dealer Attitudes," Journal of Marketing Research, 32 (August), 348-56.

Lagace, R., R. Dahlstrom, and J. Gassenheimer (1991), "The Relevance of Ethical Salesperson Behaviour on Relationship Quality: The Pharmaceutical Industry," Journal of Personal Selling and Sales Management, 4, 38-47

Lee, G. and H. Lin. (2005). Customer Perceptions of E-service Quality in online shopping. International Journal of Retail and Distribution Management, 33(2), 161-176.

Lemon, K.N., Rust, R.T., and Zeithaml, V.A. "What Drives Customer Equity, " Marketing Management (10:1), 20- 252001.

Leuthesser, L. (1997), "Supplier Relational Behaviour: An Empirical Assessment," Industrial Marketing Management, 26, 245-54.

Loyalty," Journal of Business Research, 60, 21-31.

Moorman, C., G. Zaltman, and R. Deshpande (1992), "Relationships Between Providers and Users of Market Research: The Dynamics of Trust Within and Between Organizations," Journal of Marketing Research, 29 (August), 314-28.

Moorman, C.; Deshpande, R.; and Zaltman, G. (1993). Relationship between Providers and Users of Market Research: The Role of Personal Trust, Marketing Science Institute, Cambridge, MA. DOI: 10.2307/1252059.

Morgan, R. and S. Hunt (1994), "The Commitment-Trust Theory of Relationship Science, 26 (3), 242-49.

Naudé, P. and F. Buttle (2000), "Assessing Relationship Quality," Industrial Marketing Management, 29, 351-61.

Oliver, R. (1980). A Cognitive Model of the Antecedents and Consequences of Satisfaction Decisions. Journal of Marketing Research, 17 (4), 460-469.

Oliver, Richard, L (1999), "Whence Consumer Loyalty?" Journal of Marketing, 63 (special issue 1999), 33-44.

O'Malley, L., and Tynan, C. (2000). Relationship Marketing in Consumer Markets-Rhetoric or Reality? European Journal of Marketing 34(7), 797-815 DOI: https://doi.org/10.1108/03090560010331225

O’Malley, L. and C. Tynan (1999), "The Utility of the Relationship Metaphor in Consumer Markets: A Critical Evaluation," Journal of Marketing Management, 15, 587-602.

O’Malley, L. and C. Tynan (2000), "Relationship Marketing in Consumer Markets: Rhetoric or Reality?" European Journal of Marketing, 34 (7), 797-815.

O'Malley, L.; Patterson, M.; and Kelly-Holmes, H. (2008). Death of a Metaphor: Reviewing the Marketing as Relationships' Frame, Marketing Theory 8(2), 167-187. DOI: https://doi.org/10.1177/1470593108089203 
Palmatier, R. W., R. P. Dant, D. Grewal, and K. R. Evans (2006), "Factors Influencing the Effectiveness of Relationship Marketing: A Meta-Analysis," Journal of Marketing, 70 (4), 136-53.

Palmatier, R. W., R. P. Dant, D. Grewal, and K. R. Evans (2006), "Factors Influencing the Effectiveness of Relationship Marketing: A Meta-Analysis," Journal of Marketing, 70 (4), 136-53.

Palmatier, R.W., Dant, R.P., Grewal, D., and Evans, K.R. (2006). "Factors Influencing the Effectiveness of Relationship Marketing: A Meta-Analysis," Journal of Marketing (70), $136-153$.

Parsons, A. (2002), "What Determines Buyer-Seller Relationship Quality? An Investigation from the Buyer's Perspective," The Journal of Supply Chain Management (Spring), 412.

Pressey, A. and B. Mathews (2000), "Barriers to Relationship Marketing in Consumer Retailing," Journal of Services Marketing, 14 (3), 272-86.

Rauyruen, P. and K. Miller (2007), "Relationship Quality as a Predictor of B2B Customer Perceptions," The Service Industries Journal, 1 (3), 13-36.

Roberts, K., S. Varki, and R. Brodie (2003), "Measuring the Quality of Relationships in Consumer Services: An Empirical Study," European Journal of Marketing, 37 (1/2), 169-96.

Senge Peter, (2001), In the Art and Practice of the Learning Organization (chap 7).

Sewell Carl (2005). Customers for Life, Amazone.com.

Shcheglova, I. \& Shcheglov, S. (2010). Retention of the Restaurants' Customers, Master Thesis in Business Administration Gotland University.

Sheth, J. and A. Parvatiyar (2002), "Evolving Relationship Marketing into a Discipline," Journal of Relationship Marketing, 1 (1), 3-16.

Shneiderman, B. "Designing Trust into Online Experiences," Communications of the ACM (43:12), 57-59 2000.

Smith, J. (1998), "Buyer-Seller Relationships: Similarity, Relationship Management, and Quality," Psychology and Marketing, 15 (1), 3-21.

Storbacka, K.; T. Strandvik and C. Grönroos (1994) "Managing Customer Relationships for Profit: The analyzed, Dynamics of Relationship Quality", International Journal of Service Industry Management, 5, 5, pp. 21-38.

Ulaga, W., and Eggert, A. (2006). Relationship Value and Relationship Quality: Broadening the Nomological Network of Business-to-Business Relationships, European Journal of Marketing 40(3/4), 311-327. DOI:

Vargo, S. and R. Lusch (2004), "Evolving to a New Dominant Logic for Marketing," Journal of Marketing, 68 (January), 1-17.

Vieira, A.L. (2001), "A Fidelização de Clientes na Banca Através do Marketing Relacional: O Caso das PME Portuguesas (Keeping Bank Clients Through Relationship Marketing: The Case of Portuguese Small/Medium Sized Firms)," Revista Portuguesa de Marketing (Portuguese Journal of Marketing), 10, 89-112.

Walter, A, T Muller, G Helfert, and T Ritter (2003), "Functions of Industrial Supplier Relationships and their Impact on Relationship Quality," Industrial Marketing Management, 32, 159-69.

Ward Susan, (2009). Customer Relationship Management, About.com Wong, A., and Sohal, A. (2002). Customers' Perspectives on Service Quality and Relationship Quality in Retail Encounters, Managing Service Quality: An International Journal 12(6), 424-433. DOI: https://doi.org/10.1108/09604520210451902 
Wong, Y.H.; Hung, H.; and Chow, W.K. (2007). Mediating Effects of Relationship Quality on Customer Relationships: An Empirical Study in Hong Kong, Marketing Intelligence \& Planning 25(6), 581-596. DOI: https://doi.org/10.1108/02634500710819950

Woo, K. and C. T. Ennew (2004), "Business-to-Business Relationship Quality: An IMP Interaction-Based Conceptualisation and Measurement," European Journal of Marketing, 38 (9/10), 1252-71.

Wray, B.; Palmer, A.; and Bejou, D. (1994). Using Neural Network Analysis to Evaluate Buyer-Seller Relationships, European Journal of Marketing 28(10), 32-48. DOI: https://doi.org/10.1108/03090569410075777

Wulf, K.D.; Odekerken-Schröder, G.; and Iacobucci, D. (2001). Investments in Consumer Relationships: A Cross-Country and Cross-Industry Exploration, Journal of Marketing 65(4), 33-50. DOI: https://doi.org/10.1509/jmkg.65.4.33.18386 